\title{
Bellman-Ford Algorithm for Completion of Route Determination: An Experimental Study
}

\author{
Ari Muzakir ${ }^{1}$, Hutrianto ${ }^{2}$ \\ ${ }^{1,2}$ Faculty of Computer Science, Universitas Bina Darma, J1. A. Yani No.03, Palembang 30264, Indonesia
}

\section{ARTICLE INFO}

\section{Article history's:}

Received 11 June 2020

Revised 27 June 2020,

Accepted 25 July 2020

\section{Keywords:}

Bellman-Ford Algorithm,

Shortest route search,

Traveling Salesman Problem,

A review of Algorithms,

Experimental study.

\begin{abstract}
In this study a review of the existing Bellman-Ford Algorithm by conducting tests to see the accuracy of the route data or the shortest route. In this study there are fifth locations that will be tested to see whether the route is really in accordance with the actual situation. The shortest path is part of the field of graph theory. If a graph has weight, then in the case of the shortest route, how can we do the minimization of the total weight of the route. This is what was done in this study to see how optimal the Bellman-Ford Algorithm is in handling the shortest route so that it is more accurate. The fifth Mall data is the most frequently visited by people in the city of Palembang. The five malls are Opi Mall, International Plaza, Palembang Indah Mall, Palembang Square and Palembang Icon. The conclusion from the results of this study is that the Bellman-Ford Algorithm is more complicated to do in the search for calculations manually on the completion of the Traveling Salesman Problem (TSP), but this algorithm is better in terms of finding optimal solutions and solving singe pair routes.
\end{abstract}

This work is licensed under a Creative Commons Attribution-Share Alike 4.0

Corresponding Author:

Ari Muzakir,

Faculty of Computer Science, Universitas Bina Darma, Jl. A. Yani No.03, Palembang 30264, Indonesia. Email: arimuzakir@gmail.com

\section{INTRODUCTION}

In the problems of daily life, finding the fastest route is still the priority of everyone, both going and traveling from one place to another. Nowadays, for every traveler, people always look for the fastest path to get to their destination immediately by utilizing digital maps. Digital maps utilize algorithm optimization so that the level of accuracy gets better. Some popular algorithms that can solve problems in finding the shortest route include Dijkstra's Algorithm, Bellman-Ford Algorithm, Branch and Bound Algorithm, A-star Algorithm, Floyd-Warshall Algorithm, Ant Colony Algorithm, Vector Distance Algorithm, Ford-Fulkerson Algorithm [1]. The algorithm basically utilizes a graph model to facilitate the determination of nodes. Graph is a very complex and complicated mathematical model, but it can still be a solution that helps in various forms of a particular case. Graph models are very helpful in terms of modeling a problem [1] [2]. In the case of the shortest route, the graph used is a weighted graph which from each side of the graph is given a value or weighting [3]. In this study using the Bellman-Ford Algorithm which is only used if there is a negative side [4]. So that in this study obtained two research objectives namely knowing the efficiency of the algorithm in the shortest route in terms of calculation and testing the algorithm in solving the shortest path problem.

In determining the shortest route from a source node, the Bellman-Ford Algorithm will calculate the shortest distance (from one particular vertex source) on a graph [1]. The purpose of one source is that this algorithm calculates all the shortest distances that start from one particular vertex point to all other vertices in a weighted and directed graph [5] [6]. Besides that, this algorithm uses $\mathrm{d}[\mathrm{u}]$ as the upper limit with the distance $\mathrm{d}[\mathrm{u}, \mathrm{v}]$ from $\mathrm{u}$ to $\mathrm{v}$. This algorithm initializes the distance of the source point to zero and all other points (to infinity). Progressively this algorithm makes improvements (updating) the distance at each source point to the point $\mathrm{v}$ in $\mathrm{V}$ until it reaches the Boolean TRUE theorem that the negative distance contains a non-negative 
circle then the point can be reached from the source point [7], and in other conditions it says Boolean FALSE [8] [9]. In its implementation, this algorithm also produces a path which is the result of finding the shortest path [10]. The application of the Bellman-Ford Algorithm in a company location search application for example by determining the company's destination [11], the user's starting point, the distance of the user's position to the position of the destination [12].

In this study, the focus of the use of the Bellman-Ford Algorithm is as part of the simulation application for locating the location of a mall in Palembang by looking at several points or the closest node to facilitate the identification process. Samples in the simulation use Mall data in the city of Palembang as many as 5 large locations in the city of Palembang. The fifth Mall data is the most frequently visited by people in the city of Palembang. The five malls are OPI Mall, International Plaza, Palembang Indah Mall, Palembang Square and Palembang Icon.

\section{RESEARCH METHOD}

The method used in the simulation process and application development uses rational unified process (RUP). The iterative software development approach is repeated (iterative), focused on architecture (architecture centric), more directed based on use cases (use case-driven) [13] [14]. While the research method used is the experimental method approach [15]. Research within the scope of the experiment is basically laboratory, meaning that this research method is considered the most possible to conduct a hypothesis test between the causal relationship of fulfilling internal validity [16].

In this study, to conduct software analysis and design using the RUP development approach with the four phases owned as in Figure 1.

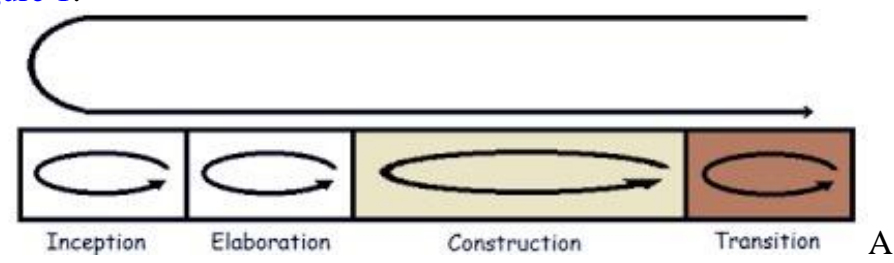

Fig 1. Lifecycle of the RUP Approach [13].

a. Inception

This stage is more modeling the business processes needed (business modeling) and defining the need for a system to be made (requirements).

b. Elaboration

This stage is more focused on system architecture planning. This stage can also detect whether the desired system architecture can be made or not. Detecting the risks that might occur from the architecture created. This stage is more on system analysis and design and system implementation that focuses on the prototype of the system (prototype).

c. Construction

This stage focuses on developing components and system features. This stage is more on the implementation and testing of systems that focus on implementing software in the program code. This stage produces a software product which is a prerequisite for the Initial Operational Capability Milestone or initial operational capability threshold.

d. Transition

This stage is more on the deployment or installation of the system so that it can be understood by the user. This stage produces a software product which is a prerequisite for the Initial Operational Capability Milestone or initial operational capability threshold. Activities at this stage include user training, system maintenance and testing whether or not it meets user expectations.

Next to conduct experiments with the RUP approach, the Bellman-Ford Algorithm is used to help the optimization process of determining the nearest path of the intended object [12]. The object of this research is the location of malls in Palembang. This algorithm must be in accordance with the procedure so that it can produce an optimal point and no errors occur. The pseudocodes in this algorithm is as follows [17] [2]:

1. INITIALIZE-SINGLE-SOURCE $(\mathrm{G}, \mathrm{s})$

2. for each vertex $i=1$ to $V(G)-1$ do

3. for each edge $(u, v)$ in $E[G]$ do

4. $\operatorname{RELAX}(\mathrm{u}, \mathrm{v}, \mathrm{w})$

5. For each edge $(\mathrm{u}, \mathrm{v})$ in $\mathrm{E}[\mathrm{G}]$ do 


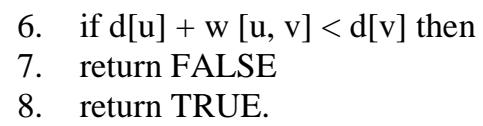

This algorithm was chosen because it has the reliability in handling cases of negative weighted graphs, can display alternative pathways, and the level of complexity of this algorithm is not too complicated [5] [17]. However, this algorithm also has a weakness which is a graph that has a negative cycle [1][2], so for graphs that have negative cycles it cannot calculate the shortest path. Following the flow of the bellman ford algorithm procedure as in algorithm 1 [1].

Data: G, s

Result: shortest paths between $\mathrm{s}$ and any other vertex of $\mathrm{G}$; if there exists a negative cycle, it outputs its existence

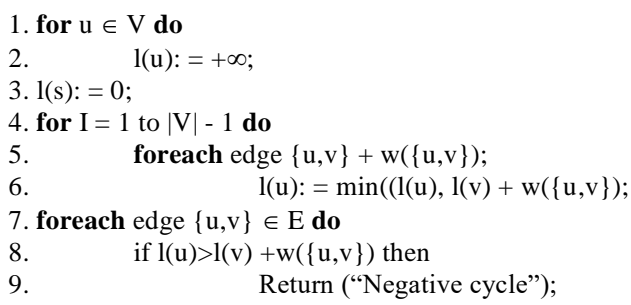

Script 1. Bellman-Ford Shortest Path Algorithm [1]

\subsection{Design}

The design process carried out in this simulation involves the admin and user in every interaction. Users can use by accessing using a mobile web device or browser as in Figure 2.

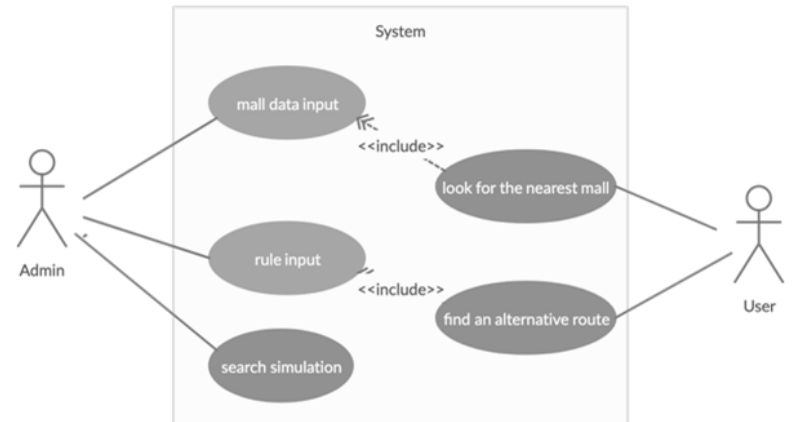

Fig 2. User interaction with the system

Next, to see the activities that occur between the admin and the user, an activity diagram is designed. Each sequence of activities described is a defined business process system, sequence or grouping of views from the interface where each activity is considered to have a display interface design, test design where each activity is considered to require a test that needs to be defined test cases and menu designs displayed on the software. The following activities occur in the application shown in Figure 3.

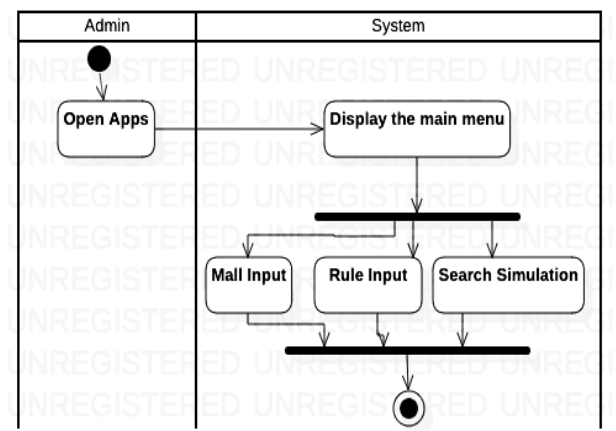

(a) Admin activity diagram

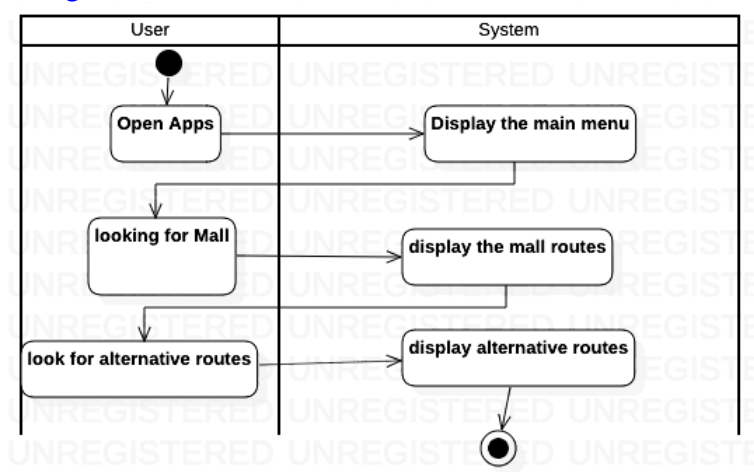

(b) User activity diagram

Fig 3. Activity diagram in the mall route search system 


\subsection{Data Sample}

The sample in this study used Mall data in Palembang (Table 1) as many as 5 large locations in the city of Palembang. The fifth Mall data is the most frequently visited by people in the city of Palembang. The five malls are OPI Mall, International Plaza, Palembang Indah Mall, Palembang Square and Palembang Icon. The starting point (node) in this simulation is Bina Darma University (shortened in UBD), which is located at Ahmad Yani Street No.3 Silaberanti Village, Seberang Ulu 1 District, Palembang.

Table 1. Data Sample starting point from UBD

\begin{tabular}{lll}
\hline No. & Destination Mall & Mileage (Meters) \\
\hline 1 & International Plaza & 1500 \\
2 & Palembang Indah Mall & 1610 \\
3 & Palembang Icon & 2340 \\
4 & Palembang Square & 2660 \\
5 & OPI Mall & 2920 \\
\hline
\end{tabular}

\section{RESULTS AND DISCUSSION}

In this discussion, researchers conducted a test using 1 Mall data from 5 existing data. The reason is because of the limitations of the pages that are allowed, so if of the fifth data discussed there will certainly not be enough pages. However, for testing the fifth route of the mall data we will present it in Table 4 . The data to be tested is the route from UBD to OPI Mall with 2 alternative routes, where the starting point is symbolized by the letter $\mathrm{S}$ and the other points are symbolized by numbers $2-13$. The following are two alternative path test data, the calculation process of the Bellman-Ford Algorithm, and the interactions of each visit can be seen in Table 2 and Table 3 and Figure 4.

Table 2. Alternative Pathways 1 and Alternative 2 testing data

\begin{tabular}{lll}
\hline Starting Point & Alternative Pathway 1 & Alternative Pathway 2 \\
\hline UBD & Flyover Jakabaring & Flyover Jakabaring \\
& Lrt Kejaksaan Station & Lrt Kejaksaan Station \\
& Pangeran Ratu Street & Pangeran Ratu Street \\
& Pasar Induk market & LRT Jakababaring \\
& & Station \\
& Yusnawati tailor & Warung Nasi Chintya \\
& Depot Kusen, Pipa Raya & DJKA Palembang \\
&
\end{tabular}

Street

Alfamart Opi Raya Opi Mall

Perumnas GGS

Opi Mall

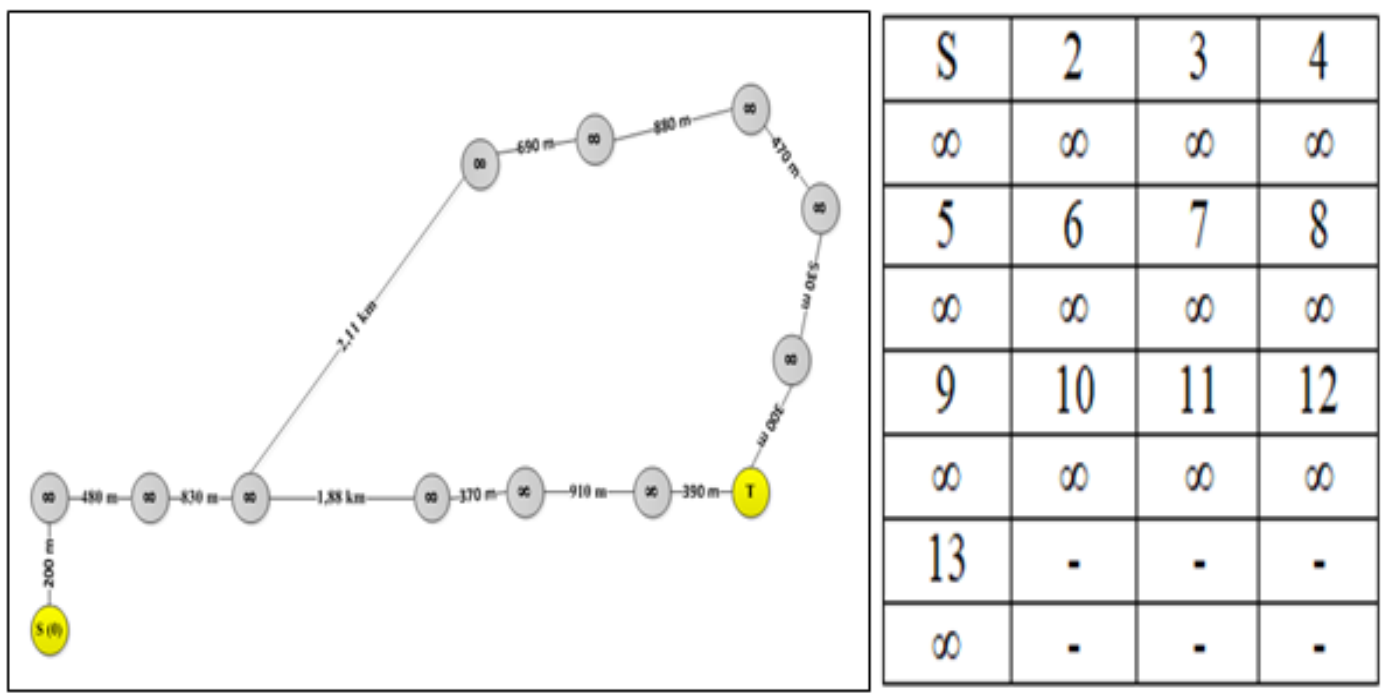

Fig 4. Stage of grading each Node 
Table 3. Iteration of each node point

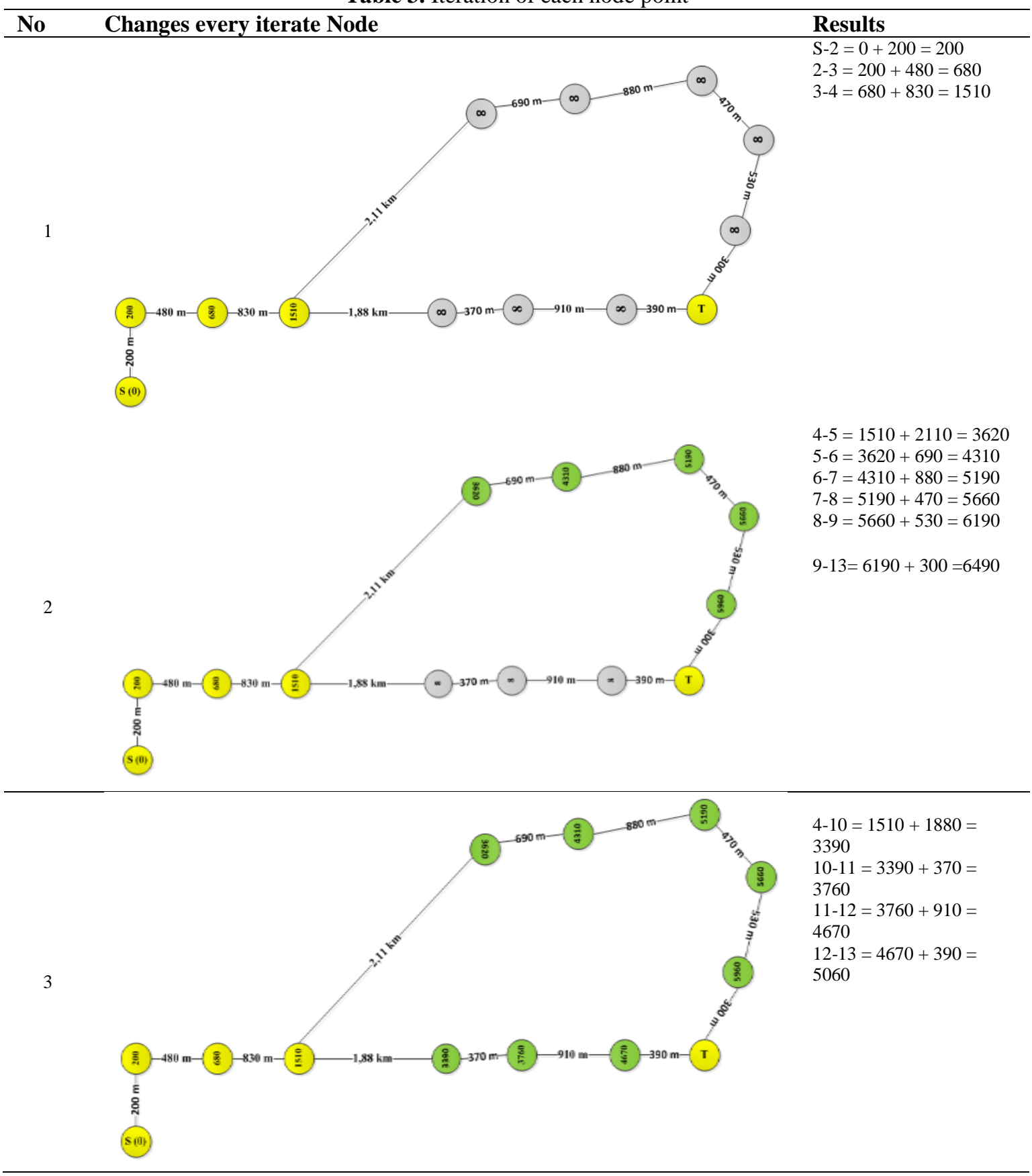

Based on the results, the route from point 1 to point 13 there are three iterations are:

1. First iteration

Iteration in table 3 number 1 , namely iteration from point 1 to point 2, 3 and 4 . In the first iteration point 2 is filled with the distance from point 1 to point 2 , point 3 is filled with distance from point 2 to point 3 , point 4 is filled with the distance from point 3 to point 4 obtained the minimum distance from point 1 to point 2 is $0+200=200 \mathrm{~m}$, point 2 to point 3 is $200+480=680 \mathrm{~m}$ and point 3 to point 4 is $680+830=1510 \mathrm{~m}$.

2. Second iteration

Iteration in table 3 number 2, namely the first iteration of point 5 is filled with the distance from point 4 to point 5 , point 6 is filled with the distance from point 5 to point 6 , point 7 is filled with the distance from point 6 to point 7 , point 8 is filled with distance from point 7 to point 8 , point 9 is filled with the distance from point 8 to point 9 , point 13 is filled with the distance from point 9 to point 13 , 
the minimum distance from point 4 to point 5 is $1510+2110=3620 \mathrm{~m}$, point 5 to point 6 is $3620+$ $690=4310 \mathrm{~m}$, point 6 to point 7 is $4310+880=5190 \mathrm{~m}$, point 7 to point 8 is $5190+470=5660 \mathrm{~m}$, point 8 to point 9 is $5660+530=6190 \mathrm{~m}$, and, point 9 to point 13 is $6190+300=6490 \mathrm{~m}$.

3. Third Iteration

The iteration in table 3 number 2 is the first iteration of point 10 filled with the distance from point 4 to point 10 , point 11 is filled with the distance from point 10 to point 11 , point 12 is filled with distance from point 11 to point 12 , and point 13 is filled with the distance from point 12 to point 13 obtained the minimum distance from point 4 to point 10 is $1510+1880=3390 \mathrm{~m}$, point 10 to point 11 is $3390+370=3760 \mathrm{~m}$, point 11 to point 12 is $3760+910=4670 \mathrm{~m}$, point 12 to point 13 is 4670 $+390=5060 \mathrm{~m}$.

The following is the recapitulation results from the above calculations, namely:

1. The first route is 1-2-3-4-5-6-7-8-9-13 with a distance of $6490 \mathrm{~m} /(6.49 \mathrm{~km})$.

2. The second route is 1-2-3-4-10-11-12-13 with a distance of $5060 \mathrm{~m} /(5.06 \mathrm{~km})$.

Table 4. The results of testing the five mall routes

\begin{tabular}{|c|c|c|c|c|}
\hline No & Starting Point & Destination & $\begin{array}{l}\text { Mileage } \\
\text { (Meters) }\end{array}$ & Pathway \\
\hline 1 & UBD & $\begin{array}{l}\text { International } \\
\text { Plaza Mall } \\
\text { (IP) }\end{array}$ & 3390 & $\begin{array}{l}\text { UBD } \rightarrow \text { Flyover Jakabaring } \rightarrow \\
\text { Bundunds of Air Mancur } \rightarrow \text { Masjid } \\
\text { Agung } \rightarrow \text { Puspita Photo Printing } \rightarrow \\
\text { Agung Shop Sport } \rightarrow \text { IP. }\end{array}$ \\
\hline 2 & UBD & OPI Mall & 5060 & $\begin{array}{l}\text { UBD } \rightarrow \text { Flyover Jakabaring } \rightarrow \text { LRT } \\
\text { Kejaksaan Station } \rightarrow \text { Pangeran Ratu } \\
\text { Street } \rightarrow \text { LRT Jakabaring } \\
\text { Station } \rightarrow \text { Warung Nasi } \\
\text { Chintya } \rightarrow \text { DJKA Palembang } \rightarrow \text { OPI } \\
\text { Mall. }\end{array}$ \\
\hline 3 & UBD & $\begin{array}{l}\text { Palembang } \\
\text { Indah Mall } \\
\quad(\text { PIM })\end{array}$ & 3420 & $\begin{array}{l}\text { UBD } \rightarrow \text { Flyover Jakabaring } \rightarrow \\
\text { Bundunds of Air Mancur } \rightarrow \text { Mayor's } \\
\text { office } \rightarrow \text { Hospital for Lungs } \rightarrow \text { South } \\
\text { Station } \rightarrow \text { Red Light PIM } \rightarrow \text { PIM. }\end{array}$ \\
\hline 4 & UBD & $\begin{array}{l}\text { Palembang } \\
\text { Icon Mall } \\
\quad(\mathrm{PI})\end{array}$ & 4130 & $\begin{array}{l}\text { UBD } \rightarrow \text { Flyover Jakabaring } \rightarrow \\
\text { Bundunds of Air Mancur } \rightarrow \text { Puspita } \\
\text { Photo Printing } \rightarrow \text { Agung Shop Sport } \rightarrow \\
\text { Agate Sales Center Cinde Market } \\
(\text { cinde }) \rightarrow \text { Intersection } 4 \text { Charitas } \\
\text { Hospital } \rightarrow \text { Dinas Perhubungan Office } \\
\rightarrow \text { Palembang emas Darusalam } \\
\text { Park } \rightarrow \text { PI }\end{array}$ \\
\hline 5 & UBD & $\begin{array}{l}\text { Palembang } \\
\text { Square Mall } \\
\quad(\mathrm{PS})\end{array}$ & 4770 & $\begin{array}{l}\text { UBD } \rightarrow \text { Flyover Jakabaring } \rightarrow \\
\text { Bundunds of Air Mancur } \rightarrow \text { Puspita } \\
\text { Photo Printing } \rightarrow \text { Agung Shop Sport } \rightarrow \\
\text { Agate Sales Center Cinde Market } \\
\text { (cinde) } \rightarrow \text { Intersection } 4 \text { Charitas } \\
\text { Hospital } \rightarrow \text { Dinas Perhubungan } \\
\text { Office } \rightarrow \text { Palembang emas Darusalam } \\
\text { Park } \rightarrow \text { PS }\end{array}$ \\
\hline
\end{tabular}

\section{CONCLUSION}

The results of this study, the Bellman-Ford Algorithm is more complicated to do in the search for calculations manually on the completion of the Traveling Salesman Problem (TSP), but this algorithm is better in terms of finding optimal solutions and solving singe pair routes. 


\section{REFERENCES}

[1] R. Dondi, G. Mauri, and I. Zoppis, "Graph Algorithms," in Encyclopedia of Bioinformatics and Computational Biology, Elsevier, 2019, pp. 940-949.

[2] R. Bellman, "On a routing problem," Q. Appl. Math., vol. 16, no. 1, pp. 87-90, 1958. doi: 10.1090/qam/102435

[3] J. R. S. C. Mateo, "Weighted Sum Method and Weighted Product Method," in Multi Criteria Analysis in the Renewable Energy Industry, J. R. San Cristóbal Mateo, Ed. London: Springer, 2012, pp. 19-22. doi: 10.1007/9781-4471-2346-0_4

[4] A. J. J. M. Marcelis, "On the classification of attribute evaluation algorithms," Sci. Comput. Program., vol. 14, no. 1, pp. 1-24, Jun. 1990, doi: 10.1016/0167-6423(90)90055-I.

[5] Neha and A. Kaushik, "Extended Bellman Ford Algorithm with Optimized Time of Computation," in Proceedings of International Conference on ICT for Sustainable Development, vol. 409, S. C. Satapathy, A. Joshi, N. Modi, and N. Pathak, Eds. Singapore: Springer Singapore, 2016, pp. 241-247. doi: 10.1007/978-981-10-0135-2_23

[6] C. Ramadani, "Dasar Algoritma dan struktur data dengan Bahasa Java," Yogyak. Penerbit Andi, 2015.

[7] V. Patel and C. Bagar, "A survey paper of Bellman-Ford algorithm and Dijkstra algorithm for finding shortest path in GIS application,” Int. J. P2P Netw. Trends Technol., vol. 5, pp. 1-4, 2014. Online

[8] R. Mehrotra and S. Budhiraja, "A Comparative Study between Bellman-Ford Algorithm and Dijkstras- Algorithms," Internatonal Journal of Innovative Research in Technology (IJIRT), vol. 1, no. 5, p. 3, 2014. Online

[9] N. Nggufron, R. Rochmad, and M. Mashuri, "Pencarian Rute Terbaik Pemadam Kebakaran Kota Semarang Menggunakan Algoritma Dijkstra dengan Logika Fuzzy sebagai Penentu Bobot pada Graf,” Unnes J. Math., vol. 8, no. 1, pp. 40-49, 2019. doi: 10.15294/ujm.v8i1.19461

[10] F. Anggraini and S. Mingparwoto, "Penerapan Metode Algoritma Bellman-Ford Dalam Aplikasi Pencarian Lokasi Perseroan Terbatas di PT. Jakarta Industrial Estate Pulogadung (PT. JIEP),” J. Teknol., vol. 7, no. 1, pp. 28-34, 2015. doi: 10.24853/jurtek.7.1.28-34

[11] D. T. Wiyanti, "Algoritma Optimasi Untuk Penyelesaian Traveling Salesman Problem," J. Transform., vol. 11, no. 1, pp. 1-6, Jul. 2013, doi: 10.26623/transformatika. v11i1.76.

[12] J. O. Agung, T. Efendi, and H. Agung, "Analisis Perbandingan Algoritma Floyd-Warshall Dengan Algoritma Bellman-Ford Dalam Pencarian Rute Terpendek Menuju Museum di Jakarta," J Sains Dan Teknol, vol. 5, no. 1, pp. 1-7, 2018. Online

[13] P. Kroll and P. Kruchten, the rational unified process made easy: a practitioner's guide to the RUP. AddisonWesley Professional, 2003.

[14] A. S. Rosa, "Rekayasa perangkat lunak terstruktur dan berorientasi objek," 2016.

[15] H. Darmadi, "Metode penelitian pendidikan dan sosial," Bdg. Alf., 2014.

[16] A. Jaedun, "Pengembangan Profesionalisme Guru Melalui Penulisan Karya Tulis Ilmiah," 2011, vol. 1. Online

[17] Thippeswamy.K, Hanumanthappa.J, and Manjaiah, "A Study on Contrast and Comparison between Bellman-Ford algorithm and Dijkstra's Algorithms," National Conference on wireless Networks-09 (NCOWN-2010). Online 